\title{
Aluminum Determination for Tri-calcium Phosphate (TCP) Anhydrous Powder by Flame Atomic Absorption Spectrophotometer
}

\author{
Y. Yildiz ${ }^{*}$, M. Dasgupta \\ Complete Analysis Laboratories, Analytical Research Department, Parsippany, NJ, USA
}

Email address:

sayatoglu@yahoo.com (Y. Yildiz)

${ }^{*}$ Corresponding author

\section{To cite this article:}

Y. Yildiz, M. Dasgupta. Aluminum Determination for Tri-calcium Phosphate (TCP) Anhydrous Powder by Flame Atomic Absorption Spectrophotometer. Science Journal of Analytical Chemistry. Vol. 4, No. 3, 2016, pp. 22-25. doi: 10.11648/j.sjac.20160403.11

Received: March 19, 2016; Accepted: April 7, 2016; Published: April 27, 2016

\begin{abstract}
Tricalcium Phosphate Anhydrous Powder typically contains 300 to $400 \mathrm{mg} / \mathrm{Kg}$ (w/w) of aluminum. This level can be determined utilizing AAS and standard based on known standards. In this study, we have determined the amount of aluminum metal present in sample of Tricalcium Phosphate Anhydrous Powder using Atomic Absorption Spectrophotometer (AAS). The method has high precision and accuracy. The results of aluminum determinations obtained by employment of $\mathrm{N}_{2} \mathrm{O}-$ $\mathrm{C}_{2} \mathrm{H}_{2}$ flame AAS methods. Great care is necessary for preparation of the blank. The need to subtract blank with standard calibration curve this was done automatically. The accuracy was checked with recovery test of aluminum added to the sample before analysis. With employment of AAS method $98.5 \%$ and $99.0 \%$ of added aluminum was recovered. The detection limit for the determination of $\mathrm{Al}$ was $0.5 \mathrm{mg} / \mathrm{Kg}$ and results meet the requirements.
\end{abstract}

Keywords: Tricalcium Phosphate, Aluminum Determination, Flame Atomic Absorption Spectrophotometer

\section{Introduction}

Tri-calcium phosphate (TCP) is a calcium salt of phosphoric acid with the chemical formula $\mathrm{Ca}_{3}\left(\mathrm{PO}_{4}\right)_{2}$. It is also known as tri-basic calcium phosphate, calcium orthophosphate, tert-calcium phosphate and bone phosphate of lime. Tri-calcium phosphate occurs naturally in several forms, including as a rock, in milk, in the skeletons and teeth of animals. Calcium phosphate rocks have a content of 30\% to $40 \% \mathrm{P}_{2} \mathrm{O}_{5}$ in weight. The human body needs phosphorus as well as calcium, and tri-calcium phosphate supplies both. Tri-calcium phosphate is an important raw material for the production of phosphoric acid and fertilizers [1]. It is commonly used in dental powders, and medically as an antiacid or calcium supplement. Aluminum is most abundant metal in earth's crust, being found in many rocks and minerals. Natural and seawater vary widely in aluminum content. Aluminum is recognized as an important toxic substance causing considerable morbidity and mortality, particularly in patients with chronic renal failure. This toxicity of aluminum is governed by its bioavailability [2].
Nevertheless, the excessive ingestion of aluminum can influence negatively the human organism disturbing calcium and phosphate metabolisms and thus damaging the bone system. Moreover, the accumulation of high amounts of aluminum in the brain is associated to Alzheimer disease, senescence symptoms and amnesia of young people [3-4]. Human beings are exposed to aluminum from several sources such as atmospheric air, cosmetics, foods, drinking water and medicines. A lot of papers devoted to the determination of aluminum in environmental samples, food, drugs, human body have appeared in the literature for years [5-6]. Many methods for the assay of aluminum exist including Atomic Absorption Spectrometry (AAS) [7].

\section{Materials and Method}

\section{Apparatus and Chemicals}

Reagents:

Certified $1000 \mathrm{mg} / \mathrm{Lin} 5 \% \mathrm{HCl}$, Atomic Absorption Standard Aluminum Solution, Specture. Alfa Aesar, deionized doubly distilled water, analytical grade 
concentrated hydrochloric acid, analytical grade calcium carbonate, and tri-calcium phosphate were used.

\section{Equipment}

Perkin Elmer 51000PC Atomic Absorption Spectrophotometer with Aluminum lamp and 2 inch Nitrous Oxide/Acetylene burner head. 1000, 250, 100, 25, 10 and, 5 $\mathrm{mL}$ volumetric flasks.5, 10, and $25 \mathrm{~mL}$ volumetric cylinders. 5, 10 and $25 \mathrm{mLV}$ olumetric pipettes. Analytical balance (accuracy to $0.1 \mathrm{mg}$ ).

\section{Procedure}

\subsection{Standard Preparation; $100 \mathrm{mg} / \mathrm{Kg}$ Aluminum Stock Solution}

Pipet $25 \mathrm{~mL}$ of $1000 \mathrm{ppm}$ Certified Aluminum Standard solution into a $250 \mathrm{~mL}$ volumetric flask. Add $10 \mathrm{~mL}$ of concentrated $\mathrm{HCl}$. Dilute to volume with deionized water and mix well.

\subsection{Calcium Matrix Solution, $6000 \mathrm{mg} / \mathrm{Kg}$}

For the high range $\mathrm{Al}$ test, $75-200 \mathrm{mg} / \mathrm{Kg}, 1.5 \mathrm{~g}$ sample is used in $100 \mathrm{~mL}$, and standard is prepared with nearly $6000 \mathrm{mg} / \mathrm{L} \mathrm{Ca}$. The sample concentration here is higher by a factor of about ten times. Accurately weigh $15 \mathrm{~g}$ of Calcium Carbonate and transfer to a $1000 \mathrm{~mL}$ volumetric flask. Add approximately $100 \mathrm{~mL}$ deionized water and swirl to form slurry. Add concentrated $\mathrm{HCl}$ dropwise to affect dissolution. Allow the $\mathrm{CO}_{2}$ escape before subsequent additions of $\mathrm{HCl}$ to prevent the solution from bubbling out of the flask. When the calcium carbonate completely dissolves and the solution clears, dilute to volume with deionized water and mix well.

\subsection{Stock and Serial Aluminum Standards}

Into each of four $100 \mathrm{~mL}$ volumetric flask, volumetrically pipet $10 \mathrm{~mL}$ of Calcium Matrix Solution. Pipette 1.0, 3.0, 5.0, 7.0, and $10.0 \mathrm{~mL}$ of $100 \mathrm{mg} / \mathrm{L}$ working solution and $5.0 \mathrm{~mL}$ of $\mathrm{HCl}$, dilute to volume with deionized water and mix well.

Table 1. Series of Al Standards.

\begin{tabular}{lll}
\hline Working Std. Sol $(\mathbf{m L})$ & Dilute to $(\mathbf{m L})$ & $\begin{array}{l}\text { Concentration of Al } \\
\text { Standards }(\mathbf{m g} / \mathbf{L})\end{array}$ \\
\hline 0 & 100 & 0.0 \\
1 & 100 & 1.0 \\
3 & 100 & 3.0 \\
5 & 100 & 5.0 \\
7 & 100 & 7.0 \\
\hline
\end{tabular}

\subsection{Sample Preparation}

Analytically weigh $1.5 \mathrm{~g}$ grams of tri-calcium phosphate and transfer to a $100 \mathrm{~mL}$ volumetric flask. Add approximately $25 \mathrm{~mL}$ of deionized water and swirl to forma slurry. Then add $10 \mathrm{~mL}$ of concentrated $\mathrm{HCl}$ and swirl to dissolve. Adding acid to dry product can cause coagulation of the product and impede dissolution. Dilute to volume with deionized water and mix well.

\subsection{Instrument / Operating Parameters}

$\begin{array}{ll}\text { Wavelength } & 309.3 \mathrm{~nm}-\mathrm{UV} \\ \text { Slit width } & 0.7 \mathrm{~nm} \\ \text { Relative sensitivity } & 1.0 \mu \mathrm{g} / \mathrm{mL} \\ \text { Lamp Energy } & 67.0 \\ \text { Lamp current } & 25 \mathrm{~mA} \\ \text { Light Source } & \text { Hollow Cathode Lamp } \\ \text { Burner head } & \text { Nitrous Oxide/Acetylene } \\ \text { Type of Flame } & \text { Nitrous Oxide/ Acetylene flame. } \\ & \text { Reducing (rich, red) } \\ \text { Integration Time } & 1.5 \text { seconds, 0.5 seconds (for } \\ \text { Average Readings } & 3\end{array}$

\section{Experiments}

Perkin-Elmer 5100PC Atomic Absorption Spectrometer was used with a short path burner and nitrous oxide/acetylene flame optimized for highest sensitivity. The instrument was operated with hollow cathode lamp and a single element was measured. The background correction was selectable on an element by element basis. For nitrous oxide-acetylene, carbon build up on burner head may compromise integrity of data for later reading. For this reason, samples should be interspersed with standards. Water has been run between each reading. Perform AA measurements, using blank, 5 and 10 $\mathrm{mg} / \mathrm{L} \mathrm{Al}$ containing a calcium matrix that is equivalent to 1.5 $\mathrm{g}$ tricalcium phosphate in $100 \mathrm{~mL}$.

Table 2. Al calibration curve measurements.

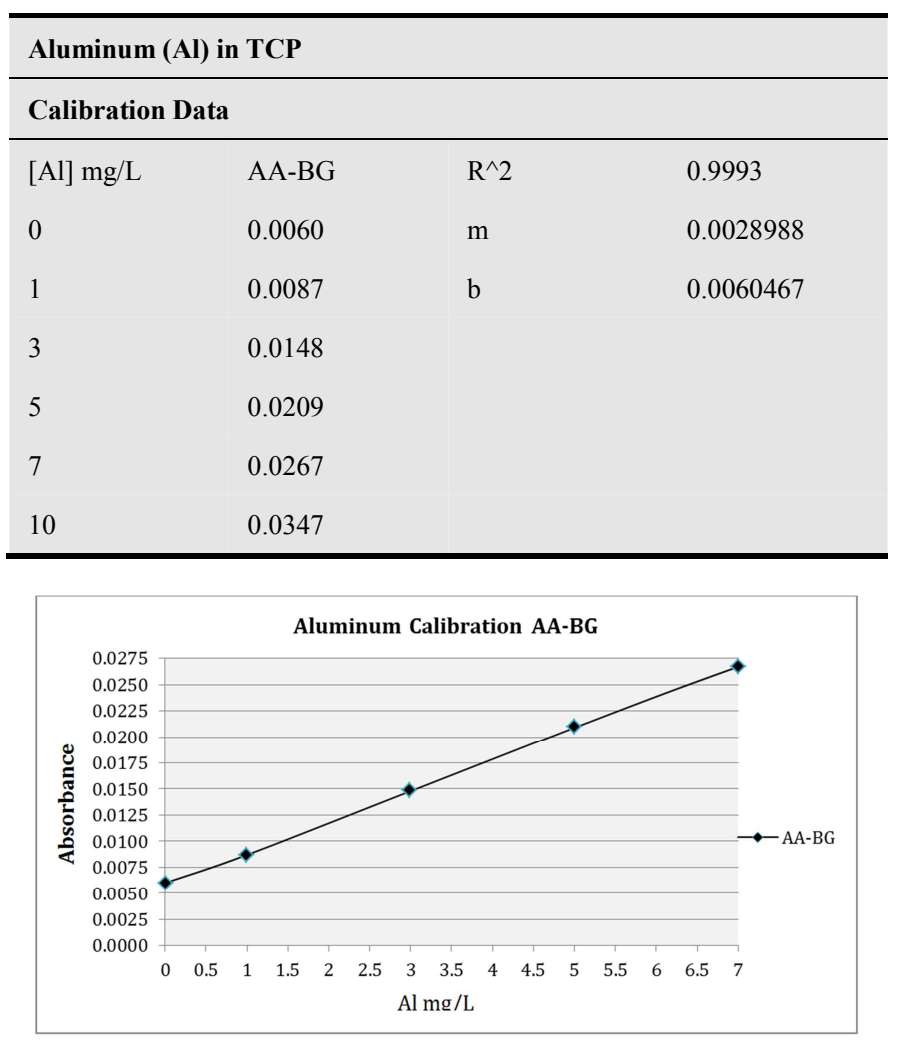

Figure 1. Calibration curve for aluminum by flame AAS. 
Table 3. Linear calibration-calculated in Excel.

\begin{tabular}{|c|c|c|c|c|c|c|c|}
\hline \multicolumn{8}{|c|}{ LINEAR CALIBRATION—Calculated in Excel } \\
\hline Sample & DF & Absorbance & Blank-correction Abs & {$[\mathrm{Al}] \mathrm{mg} / \mathrm{L}$} & W (g) & $\mathbf{V}(\mathbf{m L})$ & $\mathrm{mg} / \mathrm{kg}$ \\
\hline Water & & -0.0004 & & & & & \\
\hline $0 \mathrm{mg} / \mathrm{L}$ & 1 & 0.0048 & 0.0054 & -0.22 & & & \\
\hline Water & & -0.0008 & & & & & \\
\hline $1 \mathrm{mg} / \mathrm{L}$ & 1 & 0.0076 & 0.0086 & 0.88 & & & \\
\hline Water & & -0.0012 & & & & & \\
\hline $3 \mathrm{mg} / \mathrm{L}$ & 1 & 0.0133 & 0.0148 & 3.00 & & & \\
\hline Water & & -0.0017 & & & & & \\
\hline $5 \mathrm{mg} / \mathrm{L}$ & 1 & 0.0191 & 0.0209 & 5.11 & & & \\
\hline Water & & -0.0018 & & & & & \\
\hline $7 \mathrm{mg} / \mathrm{L}$ & 1 & 0.0245 & 0.0267 & 7.12 & & & \\
\hline Water & & -0.0026 & & & & & \\
\hline TCP Sample & 1 & 0.0044 & 0.0073 & 0.43 & 1.0002 & 10 & 4.32 \\
\hline Water & & -0.0032 & & & & & \\
\hline TCP Sample dup & 1 & 0.0039 & 0.0073 & 0.43 & 1.0019 & 10 & 4.32 \\
\hline Water & & -0.0036 & & & & & \\
\hline $10 \mathrm{mg} / \mathrm{L}$ & 1 & 0.0306 & 0.0347 & 9.87 & & & \\
\hline Water & & -0.0043 & & & & & \\
\hline
\end{tabular}

Table 4. QA / QC Study.

\begin{tabular}{|c|c|c|c|c|c|c|c|}
\hline $\begin{array}{l}\text { ml of sample } \\
\text { spike (ml) }\end{array}$ & $\begin{array}{l}\text { Concentration of } \\
\text { spike }(\mathrm{mg} / \mathrm{L})\end{array}$ & $\begin{array}{l}\text { Final volume of } \\
\text { sample (ml) }\end{array}$ & $\begin{array}{l}\text { Concentration of } \\
\text { spike } \mathrm{mg} / \mathrm{ml} \\
(\mathrm{ppm} / \mathbf{1 0 0 0})\end{array}$ & $\begin{array}{l}\text { Final volume } \\
\text { of sample } L \\
\text { (ml/1000) }\end{array}$ & $\begin{array}{l}\text { Spike } \\
\text { Concentration } \\
\text { (mg absolute) }\end{array}$ & $\begin{array}{l}\text { Spike } \\
\text { Concentration } \\
\text { (mg/L) }\end{array}$ & \\
\hline 2.00 & 10.00 & 10.0 & 0.01000 & 0.01000 & 0.020 & 2.000 & \\
\hline \multicolumn{8}{|l|}{ Sample Result } \\
\hline $\begin{array}{l}\text { LCS Result } \\
(\mathrm{mg} / \mathrm{L})\end{array}$ & QC Sample Info: & & & & & & \\
\hline \multirow{7}{*}{100.0000} & $\begin{array}{l}\text { QC Sample Final } \\
\text { Volume }(\mathrm{ml})\end{array}$ & $\begin{array}{l}\text { QC Sample } \\
\text { Result (mg/L) }\end{array}$ & $\begin{array}{l}\text { QC Sample Result } \\
\text { mg absolute (mg) }\end{array}$ & $\begin{array}{l}\text { MS Result } \\
(\mathrm{mg} / \mathrm{L})\end{array}$ & $\begin{array}{l}\text { MSD Result } \\
(\mathrm{mg} / \mathrm{L}\end{array}$ & & \\
\hline & 10 & 4.32000 & 0.0432 & 6.29000 & 6.30000 & & \\
\hline & Spike Results & & & & & & \\
\hline & & $\mathrm{ml}$ of spike (ml) & $\begin{array}{l}\text { Concentration of } \\
\text { spike }(\mathrm{mg} / \mathrm{ml})\end{array}$ & $\begin{array}{l}\text { Final volume } \\
\text { of sample (ml) }\end{array}$ & $\begin{array}{l}\text { True value of } \\
\text { spike (mg) }\end{array}$ & $\begin{array}{l}\text { Concentration in } \\
\text { sample }(\mathrm{mg} / \mathrm{L})\end{array}$ & $\begin{array}{l}\text { Absolute wt. } \\
\text { in sample (mg) }\end{array}$ \\
\hline & LCS & 1.000 & 1000 & 100 & 1000.0 & 100.0 & 10.0 \\
\hline & MS & 2.00 & 0.01 & 10.0 & 0.0200 & 6.29 & 0.0629 \\
\hline & MSD & 2.00 & 0.01 & 10.0 & 0.0200 & 6.30 & 0.0630 \\
\hline
\end{tabular}

\section{Result and Discussion}

Determined the concentration (ppm) of aluminum in the working samples using a curve fitting program; a working curve of absorbance vs. concentration (ppm). The working sample concentration has been calculated in $\mathrm{mg} / \mathrm{Kg}$ (Table 4).

The results of a single method for the detection of aluminum in the tricalcium phosphate were obtained and are shown in Figure 1 and Table 2 and 3. Calibration curve with matrix matched standards, sample's single absorbance data point was interpreted in terms of standard's slope and intercept. The need to subtract blank with standard calibration curve this was done automatically. The analysis show good linearity $\left(\mathrm{R}^{2}=0.999\right)$ (Table 4$)$, precision and accuracy (RSD $<0.5 \%$ ); recovery for spiked and spiked duplicate $(\mathrm{R}=98.5 \%$ and $99.0 \%)$ and the method detection limit was $0.5 \mathrm{mg} / \mathrm{Kg}$ and results meet the requirements.

\section{References}

[1] Ober, JA, Phosphate Rocks; U.S. Geological Survey Mineral Information.

[2] Ahmed, M. J. and J. Hossan, 1995. Spectrophotometric determination of aluminum by morin. Talanta, $42(8)$ : 1135-1142.

[3] Huseyinli, A. A., R. Aliyeva, S. Haciyeva and T. Guray, 2009. Spectrophotometric determination of aluminum and indium with 2,2,3,4-tetrahydroxy-3,5-disulphoazobenzene. Journal of Hazardous Materials, 163: 1001-1007. 
[4] Francisco, B. A., L. S. Caldas, D. M. Brum and R. J. Cassella, 2010. Novel spectrophoto metricmethod for the determination of aluminum in soda drinks packed in cans and plastic bottles. Journal of Hazardous Materials, 181: 485-490.

[5] Honorato, R. S., J. M. T. Carnerio and E. A. G. Zagatto, 2001. Spectrophotometric flow-batch determination of aluminum in plant tissues exploiting a feedback mechanism. Analytical Chimica Acta, 441:309-315.

[6] Bulut, V. N., D. Arslan, D. Ozdes, M. Soylak and M. Tufekci,
2010. Preconcentration, separation and spectrophotometric determination of aluminum (III) in water samples and dialysis concentrates at trace levels with 8-hydroxyquinoline-cobalt(II) coprecipitation system. 182: 331-336.

[7] Burguera, J. L., M. Burguera, C. Rondon, P. Carrero, M. R. Brunetto and Y. Petitde Pena, 2000. Determination of beryllium in natural and waste waters using on-line flowinjection preconcentration by precipitation: dissolution for electrothermal atomic absorption spectrometry. Talanta, 52: 27-37. 